\title{
SILVICULTURE AND CUTTING METHODS IN BRITISH COLUMBIA ${ }^{1}$
}

\author{
BY A. P. MACBEAN
}

\author{
H. R. MacMillan Export Co. Limited, Vancouver, B.C.
}

Silviculture has been defined as the art of producing and tending a forest, and is generally interpreted as embracing the fields of harvest or final cuttings, intermediate cuttings, and protection. The last, being a large and specialized branch, will not be dealt with in this paper.

Until recently silvicultural cutting methods in British Columbia were non-existent-indeed even intermediate cuttings are still almost exclusively in the experimental field. Although logging has for the most part been conducted without any conscious effort to secure a new crop, nevertheless there has been reproduction on a large proportion of the early cut-over lands. Probably more than half of the lands currently being logged are restocking naturally. Although insufficiently stocked lands extend over some million acres on the coast and nineteen million acres in the interior, there is much evidence to suggest that fire and particularly reburns have been chiefly responsible.

Probably the first commercial logging venture in British Columbia was the cutting of spars on the west coast of Vancouver Island, which were taken aboard the Felice by Capt. John Meares in 1787 for disposal in the Chinese market. The first sawmill was erected by the Hudson's Bay Company near Victoria 100 years ago and from that time the volume of timber harvested grew steadily. After the first great war the rate of cutting grew rapidly and in 1947 exceeded 4 billion f.b.m. Approximately three-quarters of this cut came from 76 thousands acres located on the lower mainland coast and Vancouver Island, which administratively composes the Vancouver Forest District. This region, which has always been first in production, contained the principal stands of Douglas fir, which continues to be the principal commercial species.

Considerable knowledge of the silvicultural requirements of the important commercial species has been accumulated, and with the possible exception of spruce, regeneration can for the most part be obtained fairly easily, particularly by comparison with some important species in other sections of the continent. In spite of this, and excepting timber sales, there are no regulations providing for compulsory restocking of forest lands, although 93 per cent of the productive acreage is publicly-owned, and although for many years over 50 per cent of the cut has come from lands not privately-held, i.e. timber licenses, leases, sales, etc.

There has been little incentive for operators to voluntarily undertake the extra costs involved to ensure restocking. Partially because of the Canadian system of retaining Crown ownership of the land, which in B.C. has been in effect since 1896, it is difficult to acquire sufficient Crown-granted lands for continuous operations. Moreover, since the methods of taxing Crowngranted lands were not conceived with sustained yield in mind, they tend to encourage timber liquidation, and over a rotation would result in prohibitive

\footnotetext{
1 Paper presented at the fortieth annual meeting of the Canadian Society of Forest Engineers, Fredericton, N.B., October 4 to 7,1948 .
} 
costs against the new crop. Since the report of the second Royal Commission of Inquiry into the Forest Resources of British Columbia in 1945, the legislature has amended the Forest Act to provide for Management Licenses designed to permit individuals and corporations to enter into sustained yield agreements with the government. The licensee is obliged to keep his lands restocked, but in view of certain opposition which has developed it is too early to estimate the extent of the acreage which will be covered by such agreements.

The first Royal Commission in 1910 considered that most forest lands would restock. No suggestions as to the regulation of logging methods were made, but it was recommended that the future Forest Service (established in 1912) investigate conditions and develop such regulations as might be found necessary to ensure restocking of valuable species. The first World War interrupted investigations, but in the twenties it became evident that generation failures were occurring. Undoubtedly the depression of the thirties and the second Great War were unfavorable periods for the introduction of regulations, but there is no evidence to indicate why action was not taken in the intervening years. In part it may be possible that the government was reluctant to forego revenues in compensation for the added costs which would be incurred by logging methods which would ensure reproduction. It is of interest to note that no action has been taken to implement the emphatic recommendation of the Second Royal Commission for compulsory restocking.

Timber sales, from which an increasing proportion of the timber cut originates, must be partially excepted from the foregoing comments. The diameter limit was early introduced into the sales contract. Primarily to reduce waste, it has possibly been of some benefit silviculturally. In recent years selection methods have been specified in the yellow pine and spruce sales of the Interior.

For the purpose of discussing the silviculture and cutting methods of the more important species the province can be divided into two regions. The mild, moist climate of the Coast has produced a mature to overmature forest of large trees which yield a heavy volume per acre. As a consequence the ox and horse, as early as the eighties, began to be supplanted by machine methods of logging, which with slight variation are applied in the several Coast typesDouglas fir, hemlock-cedar, and spruce-hemlock. The generally more rigorous climate of the Interior supports a forest which more nearly resembles those of the northern prairies and the east. Horses have been used for yarding. In recent years the truck has come into use, and to a limited extent the cat has replaced the horse for skidding.

\section{Douglas fir \\ 1. COAST}

Dr. C. D. Howe completed a survey in the fir area of the lower coast in 1914 and found reproduction on logged and burned areas to be good, excepting those subject to reburns. Up to this time, the area logged annually on individual operations had been small. Ground-lead methods of yarding had been in vogue and to some extent a form of high-grading was practised. As a result seed supply was usually adequate. Between 1910-1913 the first skidders were introduced and shortly afterwards were followed by the first 
high-lead yarding. By the end of World War I ground-lead logging had mostly disappeared. The new systems were much more destructive of residual trees within the felled area. The expansion of the industry in the twenties led to the logging of larger tracts each year and utilization became more intensive. The timber margin moved back faster and fewer scattered seed trees remained. Combined with careless and too extensive broadcast slash-burning many areas were left without adequate seed sources, which Dr. Howe had found prevalent in the restocked areas which he had investigated.

Douglas fir has good seed at intervals of roughly 3 to 5 years. The seed is fairly heavy, and effective seeding range is mostly not more than 500-600 feet. Germination and survival are generally satisfactory excepting under heavy brush or on bare southerly slopes. The seedling is inclined to be intolerant of shade. Contrary to early opinion, the seed does not remain viable in the duff for more than a year following dispersal.

Generally, clear-cutting is practised in the fir forest and from the standpoint both of economical logging and the securing of a new crop is satisfactory if a seed source be provided. This may take the form of scattered seed trees (faulty trees are satisfactory, although frequently they are not to be found), patches of scrub on knolls, etc., or marginal timber. In recent years several companies have employed the latter method which takes the form of logging in staggered settings, or as it is sometimes called, "patch logging." If the patches are not too broad (the average high-lead setting is about 1000 feet across, which is not too great) the results have been satisfactory. On poor, dry sites (say below Site Index 100) it is possible that fir could be managed on a selection system. In sound high quality stands, clear-cutting and planting have been advocated as being cheaper than leaving seed sources for natural regeneration. This practice may be sound on a small scale, but it is doubtful whether it could be applied extensively because of the difficulty of securing sufficient labor for the short planting season, except in times of depression. Under mass production nursery practice there is also the problem of securing stock of suitable racial origin.

Primarily for hazard abatement, and to make suppression of subsequent fires easier, broadcast slash burning has been widely used in the fir type, and since 1938, the year of the disastrous Campbell River fire, has been mostly compulsory. Where slash accumulations are heavy, burning is silviculturally desirable in order to provide a seed bed. Burning also encourages fir reproduction as against its common associates hemlock and cedar. However, it produces many bad results and it is evident that good management requires less burning and greater expenditures to prevent or quickly suppress accidental fires. Burning may:

1. Kill marginal timber,

2. Cause southerly and particularly steep slopes to become hotter and drier.

3. Kill thin-barked hemlock and cedar seed trees, which formed the understory of the original forest.

4. Kill patches of hemlock and cedar advance reproduction. 


\section{Hemlock}

Surveys in the hemlock, hemlock-balsam, and hemlock-cedar types have indicated that satisfactory restock has generally followed logging or logging and burning. Some small understory trees frequently remain after either skidder or high-lead logging. They are able to function as seed trees since slash burning is generally not required because of the low fire hazard in the region supporting these types. Seed may also originate from marginal timber or from groups of small unmerchantable trees.

Both hemlock and cedar produce abundant cone crops at fairly frequent intervals. Because of its small size, the seed is not as attractive to rodents and birds as Douglas fir, and it is effectively disseminated by the wind. The mild, moist summer climate favors germination and survival. Seedlings are very tolerant and are able to survive under a wide range of light conditions. Advance reproduction often becomes established under old growth.

Regeneration may prove difficult in those types which have heavy underbrush or which tend to produce a dense undergrowth. Silviculturally two types may be recognized. The open type, which includes various cedar-hemlock mixtures, occurs mostly in the lower levels and along the coast. It runs to low volume per acre, heavy underbrush, light advance reproduction and heavy slash. In the dense type, composed of hemlock or hemlock-balsam, almost all these conditions are reversed. Broadcast slash burning has been recommended in the open type in order to reduce the slash and underbrush so that regeneration may take place. It is also believed that such treatment will improve the type. It will be difficult to apply this recommendation, since under suitable conditions it will not be easy to prevent fires from escaping into adjoining country.

Although almost all logging has been accomplished by clear-cutting, the selection system could be applied in some stands. For the most part the topography is too steep or the ground too soft for the successful use of cats, which would be necessary with this system. A further difficulty is due to the susceptibility of hemlock to decay following wounding -a frequent occurrence in selective logging with tractors.

\section{Sitka Spruce}

Sitka spruce is commonly associated with hemlock, red cedar, and amabilis fir. Very little has been done to determine the silvical requirements of these types. Surveys suggest that regeneration takes place slowly, but that satisfactory stands do become established over an extended period. There is some evidence to suggest that burning may be beneficial where debris or underbrush is heavy.

\section{Thinning and Pruning}

Thinnings for piling, poles, and mining timber have been made, but usually without regard for the final crop. Lacking suitable markets, early thinnings have only been made on an experimental plot basis. Investigations suggest that Douglas fir pruning on the better sites will be economically sound. 


\section{Yellow Pine}

\section{INTERIOR}

Beginning about 1942 selection methods of cutting have been applied in yellow pine timber sales. Where yellow pine constitutes 50 per cent or more of the volume, trees to be harvested are marked. A diameter limit is applied to stands carrying less than this proportion.

The uneven-aged stands are well adapted and selection is proving effective. Overmature, stagnant, spindly-crowned trees are harvested leaving vigorous small trees with large crowns. By this procedure, trees susceptible to the bark beetle are removed. In all, 16 tree classes are recognized -4 physiological age groups, each of which is subdivided into 4 crown-vigor classes.

Previously yellow pine regeneration had not always been successful. In some cases logging had been followed by inferior species. 2. Spruce

a) Southern Interior-Selective logging was first applied experimentally in 1941 in the so-called "high-level" Engelmann spruce forest. Not all sales are marked, but the method has been used over more than 2000 acres. The stands tend to be even-aged, with possibly an understory and reproduction layer. In making partial cuttings care is required to avoid too large openings on account of the danger of windthrow. In practice an average of about $2 / 3$ the volume is removed. No definite tree classification has yet been devised on which to base marking rules-the method depends on the judgment and experience of the markers.

Whether reproduction will follow is not yet known, but the residual stand will yield an additional cut. Regeneration was unsatisfactory under the former practice of clear-cutting.

Damage from cat yarding in tree lengths is excessive. Favorable results are obtained by skidding short logs with horses.

b) North Central Interior-Surveys have shown that regeneration is generally poor following logging and/or burning of the white spruce-balsam forest. Logging to a 12-inch diameter limit has amounted to clear-cutting. Adequate restocking was found to be due to well distributed residual stands. Studies have shown that raw humus, through limiting the available moisture, restricts germination and survival. Exposure of the mineral soil results in regeneration.

Two types of mature forest have been recognized. Probably the most extensive is the climax type which has passed through several stages of maturity. In the second type, the spruce has only matured to the first generation; hardwood remnants may still be present. The first type generally carries a heavier understory. Studies suggest that a higher diameter limit be used, or that marking be practised with the object of increasing and improving the residual stand, which may be expected to develop into a second crop over a long period of years.

The second type appears to be more difficult to handle, possibly very light cutting combined with soil scarification might yield satisfactory results. 
Allen, G.S. (1942) Douglas fir, a summary of its life history, B.C. Forest Service, Res. Notes \#9.

(1944) Management recommendations for the hemlock and associated forest types of the Juan de Fuca region of south-western Vancouver Island. B.C. Forest Service, Res. Notes \#11.

Barr, P.M. (1930) The effect of soil moisture on the establishment of spruce regeneration in British Columbia. Yale Univ., School of For., Bull. \#26.

(1933) Ecological Aspects of spruce regeneration. Fifth Pacific Science Congress.

Barnes, G.H. (1937) The development of uneven-aged stands of Engetmann spruce in British Columbia. For. Chron. Vol. 13 No. 3.

Griffith, B.G. (1931) The natural regeneration of spruce in central British Columbia. For. Chron. Vol. 7, No. 4.

Hodgins, H.J. (1942) Keen's tree classification and marking rules for ponderosa pine in B.C., B.C. For. Service.

Howe, C.D. (1915) The reproduction of commercial species in the southern coastal forests of British Columbia. Commission of Conservation, Can.

Isaac, L.A. (1943) Reproductive habits of Douglas fir. Charles Lathrop Pack Forestry Foundation.

MacBean, A.P. (1941) A study of the factors affecting the reproduction of western hemlock and its associates in the Quatsino region, Vancouver Island. B.C. Forest Service.

McKinnon, F.S. (1940) Spruce regeneration, British Columbia. For. Chron. Vol. 16, special number.

(1943) An outline of the minimum requirements for management of Douglas fir. B.C. Forest Service, Res. Notes \#10.

McKinnon, F.S. (1947) Forest management in British Columbia, Fifth Br. Emp. For. Conference.

Pogue, H.M. (1946) Regeneration and growth of white spruce after logging. B.C. Forest Service, Tech. Pub. T.29.

Warrack, G: (1948) Thinning and pruning of second-growth Douglas fir in the Coastal region of B.C., B.C. For. Service, Res. Notes \# 13. 